СМУ-7.

\title{
МЕТОДИКА ОДНОВРЕМЕННОГО ОПРЕДЕЛЕНИЯ Na, K, Li, Rb и Cs В ГЕОХИМИЧЕСКИХ ОБРАЗЦАХ
}

Зак А.А., Шабанова Е.В., Васильева И.Е. ФГБУН Институт геохимии им. А.П. Виноградова СО РАН, Иркутск, Россия zak@igc.irk.ru,shev@igc.irk.ru

DOI: 10.26902/ASFE-11_87

Определение щелочных элементов $\mathrm{Na}, \mathrm{K}, \mathrm{Li}, \mathrm{Rb}$ и $\mathrm{Cs}$ в геохимических образцах необходимо для классификации и датировки. Однако распространённость щелочных металлов отличается в тысячи раз, и их одновременное определение является нетривиальной задачей.

Пламенная атомно-эмиссионная спектрометрия (ПАЭС) хотя является моноэлементным методом в отличие от рентгенофлуоресцентного анализа, атомно-эмиссионной и массспектрометрии с индуктивно связанной плазмой, позволяет определять все щелочные металлы в диапазоне от $10^{-4}$ до десятков \% мас., но требует дополнительных операций по пробоподготовке в ходе анализа - разбавления растворов и введения спектроскопических буферов. Современные спектрометры с многоканальной регистрацией спектра и широким динамическим диапазоном измерений интенсивности излучения (например, спектрометр «Колибри-2» ООО «ВМК-Оптоэлектроника», Россия [1]) обеспечивают одновременное детектирование аналитических сигналов $\mathrm{Na}, \mathrm{K}, \mathrm{Li}, \mathrm{Rb}$ и $\mathrm{Cs}$ при концентрациях, характерных для геохимических образцов. Однако для одновременного определения $\mathrm{Na}, \mathrm{K}, \mathrm{Li}, \mathrm{Rb}$ и Cs в широком концентрационном диапазоне и использования всех возможностей таких спектрометров, необходимо оптимизировать процедуру пробоподготовки проб.

Для этого проведено сравнение вариантов подготовки растворов порошковых проб разнообразного состава, таких как магматические и осадочные горные породы, донные отложения, почвы, золы углей, и выбран способ [2-3], обеспечивающий воспроизводимость процедур и стабильности аналитических сигналов, регистрируемых из растворов, срок хранения которых составляет 9 месяцев. Подобраны оптимальные условия атомизации элементов (скорость введения раствора в пламя, расход газа), способы регистрации и обработки спектров (экспозиция, время считывания, число параллельных измерений, учёт фона и расчёт интенсивности линии). Исследовано влияние концентрации кислоты и содержаний породообразующих элементов на интенсивность аналитических сигналов аналитов. Показано, что градуировка по растворам государственных стандартных образцов (ГСО) при использовании метода постоянного графика обеспечила минимизацию матричных влияний.

Разработанная методика позволяет одновременно без дополнительных процедур определять элементы в диапазонах (\% мас.): $\mathrm{Na}$ 0,025-8,0; K 0,005-15,0; Li 0,0002-0,35; Rb 0,0002-0,2 и Cs 0,0002-0,02 с точностью 30-8 отн. \%. Правильность результатов анализа оценена при анализе ГСО разнообразного состава, способом стандартных добавок и межметодными сопоставлениями. Методика позволяет получить дополнительную информацию о содержаниях в пробах Са (1-31\% мас.), $\mathrm{Mn}(0,16-1,37 \%$ мас.) и $\mathrm{Sr}(0,02-$ 0,83\% мас.). Кроме этого, снижение временных затрат при одновременном определении щелочных элементов делает экономически привлекательной разработанную методику ПАЭС.

\section{Сиисок литературы}

1. Зарубин И.А., Гаранин В.Г., Лабусов В.А. // Заводск. лаборатория. Диагностика материалов. 2012. Т. 78. № 1.

Ч. II. C. 86.

2. Зак А.А., Шабанова Е.В., Васильева И.Е. // Заводск. лаборатория. Диагностика материалов. 2017. Т. 83. Ч. II, № 1, C. 38 .

3. Шабанова Е. В., Зак А. А., Васильева И. Е. // Журн. аналит. химии. 2018. Т. 73. № 9. С. 671. 